\title{
Real and Fictional Home: Constructing James Joyce's Identity in A Portrait of the Artist as a Young Man
}

Leila Baradaran Jamili ${ }^{1}$, Razie Arshadi ${ }^{*}$

${ }^{1}$ Department of English Language and Literature, Faculty of Postgraduate Department of English Language and Literature, Islamic Azad University, Boroujerd Branch, Iran

${ }^{2}$ Department of of English Language and Literature, Islamic Azad University, Boroujerd Branch, Iran

Corresponding Author: Razie Arshadi, E-mail: RazieArshadi2000@gmail.com

\section{ARTICLE INFO}

\section{Article history}

Received: August 21, 2017

Accepted: October 22, 2017

Published: December 30, 2017

Volume: 8 Issue: 6

Advance access: December 2017

Conflicts of interest: None

Funding: None

\section{Key words: \\ Cultural Identity, \\ Real Home, \\ Fictional Home, \\ Semiology}

\begin{abstract}
The present paper sheds new light on the prominent role of man's home whether real or fictional on the construction of his identity in James Joyce's (1882-1941) A Portrait of the Artist as a Young Man (1916). One of the most pressing issues and cultural contradictions of modern world is the fate of individual identity in city life. A person is defined based on his cultural identity; and when the loss of that identity is imagined, one is confronted with the thought that he will lose his sense of self and cease to be what he is. The identity involves a repression that leads to a construction of stability and security that might not exist in reality. Peter J. Burke and Jane E. Stets declare that identity means 'who you are'. Thus, to investigate one's identity one has to find a way to the cultural context that the person is brought up in it. Michael Ryan (1946-) asserts that culture is a set of unstated rules by which men live. It allows men to live together in communities by giving them shared signs and signals. Semiology, according to Roland Barthes (1915-1980), is the scientific way of deciphering the cultural signs and codes that pave the way to look into a distinct culture. Thus, it is impossible to know Joyce's characters, in particular Stephen Dedalus, without enough knowledge of Dublin as Joyce's home. Stephen metaphorically maps his home through which he can wander to shape and reshape his real self.
\end{abstract}

\section{INTRODUCTION}

Everyone has a right to a place called home and it is associated with safety, security, dignity and respect. Being without a home is being without that place in which there might be the possibility of being oneself, at ease, secure and at rest. The need for a place like that is deep and urgent in all of people. Any notion of 'home' depends upon a complex mesh of material, social and emotional factors. In practical terms, it is clear that the concept of 'home' is inextricably interlinked with cultural value systems and social power relations. 'Home' is often a desire to establish a sense of belonging in cultural or national space. Home can be understood as an emotional investment that a person makes in a particular place, which may be reinforced by repeated, ritualized ways of being. Notions of 'home' are both deeply personal and are closely bound up in cultural and historical contexts.

Furthermore, identity is closely linked to place, to key places and often to the place that one calls home. Home or Heimat is the place of native, race, root, culture and sameness. Home is not homogenous but relational; the idea of home depends on the repression of differences even within oneself. "Distance purifies a person's memory and permits him to 'transcend sensation,' to experience new feelings and to see things in their structure" (Baradaran Jamili 2006:187). The homeland is not the mute object defined by physical geography though geographers have their role to play in the national imagining; it is endowed with a personality and moral character of those who inhabit it.

In this way, a better account of the importance of culture lies in the notion of identity. If one's identity is formed within a certain culture, then it defines his fundamental perspective on the world, constitutes him as a member of a community, provides him a set of memories and aspirations, and it gives him a place which is his. The negotiation of identities is, thus, an essential process including both the subjects and objects of ethnography. It creates a binary opposition between home and abroad. The concept of identities as who one is, is best developed within structural symbolic interaction theories. Peter J. Burke and Jane E. Stets, in Identity Theory (2004), define identity by setting forward a question, "[w]hat does it mean to be who you are?" (3). They continue that, "an identity is the set of meanings that define who one is when one has got a particular role in society or he or she becomes a member of a particular group, or asserts particular characteristics that identify him or her as a unique person" (ibid). As people oc- 
cupy multiple roles, they achieve multiple identities. Both the individual and society are linked in the concept of identity. Burke and Stets admitted that according to Charles Cooley, "the individual and society are two sides of the same coin" (ibid). In other words, identifying the self becomes possible in the context of society that he is brought up in it.

In A Portrait of the Artist as a Young Man (A Portrait), James Joyce indicates to what extent man's cultural identity is tied to his home. Stephen Dedalus tries to know himself or better to say, his identity through wandering in the streets of his home/Dublin. He unfolds himself step by step on the streets. In fact, he constructs his identity at his home. Joyce reproduced Ireland and Dublin in his great masterpieces. He sees the pictures and hears the voices of his home in his works and it emphasizes his suffering from being in exile. Joyce compares the history of Ireland to the history of the world, since for Joyce home or Ireland is the world. This research uses the viewpoints of Roland Barthes and Michael Ryan to clarify the researchers' claim. As well as, the ideas of identity critics are considered by the researchers.

\section{MATERIALS AND METHOD}

The present paper aims at showing the impact of home or heimat on the construction of man's cultural identity. In this way, man's home is not an exact physical place. On the contrary, it is examined as a literary text. In order to do that Roland Barthes' semiology and Michael Ryan's cultural concepts have been selected. Unquestionably, the ideas of identity critics are taken into consideration to illuminate the main point of the paper.

Ryan in Cultural Studies (2010) declares that, a landscape would not be defined as a meaningful area if culture did not dominate it. Indeed, culture establishes values, ideas, and needs of the target community (12). He asserts when a landscape is improved by human it can be assumed as a book or a text. According to him, the transformed environment becomes "a collection of signs" whose meanings and interpretations are intentional (15). In other words, the cultural ideas of human form the meanings of signs. This landscape contains a vast range of signs such as historical, social, economic, ideological, philosophical or political signs to name a few. But they are all cultural in every sense of the word that men have made them with their minds. Thus, they can be considered as ways of men's life.

The ways of understanding and methods of reasoning are acquired through culture that one uses to read the cultural world around him. The rules of life are internalized by culture which one grows up in it. Identity, a principal course in the humanities, is bound up with culture. Identity indicates who one is as an individual being. It is very closely connected with the culture in which he lives. People learn to see, feel and think based on their culture in determined ways. Ryan expresses that, "[a]lthough I come from Ireland, I have lived long enough in American culture. [...]. My cultural identity is more American than Irish by this point" (ibid). With respect to this, one acquires an internal identity from outside himself. What one is inside himself is formed by culture which is outside.
Ryan asserts that, "I can spot someone who is 'corporate' and distinguish him or her from someone who appears

'countercultural' quite easily" (ibid). Conclusively, one learns to recognize the cultural signs of each identity while growing up in that special culture. Living in one place is like learning a dynamic dictionary that allows the meaning of its own cultural signs which makes it possible to be read, recognized, and deciphered.

Barthes, in his Mythologies (1991), articulates that, "[s]emiology is a science of forms," which examines significations apart from their content (110). Any semiology speculates a connection between two terms, a signifier and a signified. The signified is expressed by the signifie, in any semiological system with three different terms. Whereas the signifier is empty, the sign is full, it is a meaning. Normally, there are functional associations between the signifie, the signified and the sign, such as that of the part to the whole. According to Barthes, in Elements of Semiology (1986), "semiology is the science of signs that its emphasis is on the interpretation of the codes, signs and symbols in a particular culture" (18). Semiology is therefore perhaps destined to be absorbed into a trans-linguistics, the materials of which may be myth, narrative, journalism, or on the other hand objects of people's civilization, in so far they are spoken through press, prospectus, interview, conversation and perhaps even the inner language, which is ruled by the laws of imagination. The object of a future semiology is the life of signs within society. Barthes' approach derives more from semiology than from semiotics-that is, more from the study of the life of signs within society.

Barthes states that, "the city is a discourse, and this discourse is actually a language: the city speaks to its inhabitants, we speak to our city, the city where we are, simply by inhabiting it, by traversing it, by looking at it" (ibid 417). If one considers the city as a writing, one, as the city's user, is a sort of reader. Accordingly, semiology is the way of reading the language of the city. On that account, Joyce's Dublin and Dubliner's life are introduced to the readers of his works. In fact, he reaches to self- recognition through his home/Dublin.

\section{RESULTS AND DISCUSSION}

The word identity is taken from Latin iden, which is identified as the same. Baradaran Jamili, referring to Nicholas Bunnin and Jiyuan Yu, argues that, "identity has been interpreted in two ways: as singleness over time and as sameness amid difference" (2013: 9). Based on this interpretation, every person, particularly a novelist, can remain within himself in spite of many alterations. Identity may lead on to variety of questions such as the conditions of personal or individual identity. Indeed, there are two concepts about individual's identity as "sameness amid diversity" (ibid). First of all, the identity by which a person is himself, and secondly the identity that one can be distinguished from other people of the same kind.

Baradaran Jamili admitted that Rey F. Baumeister defines identity as, "a definition, an interpretation of the self" (2006: 319). It is one of the novelist's "cognitive capacities 
sophisticated enough to engage in complex self-questioning and consideration of alternatives" (ibid). There is a role for home as the agent for changes in the self that leads to define identity. When a novelist ponders over his hometown, his knowledge is altered. Consequently, a different self is revealed. The concept of identity implies that there is a constitutive linkage between forms of subjectivity, i.e. the ways in which one conceives of himself, and forms of social objectivity, the patterns of social life within which man exists. "All identities are constituted in and through particular forms of social life" (Poole 41).

Nevertheless, identity can be considered as a relation instead of a property. That is the relation between names or signs of objects. The pervasive social culture into which one is born is one of the most significant determinates of one's identity. Though it is considered that, "[t]here is no straightforward relationship between identity and social concepts such as religion, family and gender," one acquires identity through the family, social interaction and education (Prevos 2). Normally, men do not choose to acquire a culture, nor can they choose to give it up. It is rather that men's cultural identity provides the content within which they choose and sometimes the criteria on which they choose; it is not itself an object of choice. "Culture in this sense embodied in our sense of who we are in the social practices within which we exist" (Poole 106). The strength of a national identity lies in the richness of the cultural resources which are employed in forming the conception of national community. This identity provides one with a land in which he is at home, a history which is his, and a privileged access to a vast heritage of culture and creativity. Culture exists in the language that is used, the forms of social interaction in which one feels relaxed and friendly, the symbols are recognized as belongings, even in the food one eats and the games one plays.

According to Kathleen R. Arnold, in Homelessness, Citizenship, and Identity:

[t]he home as precondition for citizenship and symbol of constancy is also idealized as a place free of power, conflict and struggle, a place-an identity, a private realm, a form of life, a group vision-unmarked by difference and untouched by the power brought to bear upon it by the identities that strive to ground themselves in its place. (52)

Home is the symbol of eternity that is free from any annoying effect of society. It is a privately owned area that is protected from anything unpleasant. Arnold continues that:

[t]he home 'fulfills many needs: a place of self-expression, a vessel of memories, a refuge from the outside world, a cocoon where we can feel nurtured and let down our guard. A person without a fixed adobe is viewed with suspicion in our society, labeled 'vagrant,' or homeless person, 'hobo,' or 'street person. (57)

Man can achieve many personal needs at home. One without home either oscillates or wanders in society. No one becomes firm in the loss of stable home. Home and freedom are seriously interdependent. Though identity is not fixed by home and it is not limited to home, identity is connected to physical being that makes a continuity between past and present. Without such connection of oneself in things, one is lost. According to Arnold, home in this sense goes beyond a mere address and it is filled with social and cultural meaning. In other words, home both is an identity that overlaps and transcends the identity of citizenship and is representative of the dynamics of power that situate identity (85).

The concept of home consists of relationships and activities and, ideally, the freedom to follow these. It is perceived as tension free and a place to escape social problems. Emotions, identity, and a sense of location are involved at home that evokes unconscious emotions and ideas. Perceptions about the home are crucial in terms of self-identity; that is, the relations and integrations that make up one's identity also make up what is home. There is a secluded home for everyone that is unoccupied by terror and uncertainty.

The nation is not just a form of consciousness; it is also a form of self-consciousness. As members of the nation recognize each other through the nation, they also recognize themselves. If the nation is an imagined community, it is also a form of identity. As an imagined community, it exists as an object of consciousness. It is the public embodiment of the nation's conception of itself. As a form of identity, it exists as a mode of individual self- and other-awareness. In order to understand this dual form of existence, one needs to go beyond the concept of imagination to that of culture.

"[S]elf-awareness is a super imposed awareness"; however, the sense of identity is not just based on "the physical self but depends on meaning" since the "meaning occurs only within a contextual network of relationships" (Baradaran Jamili 2013: 9). The novelist's self-analysis; his self-interacts with the norms, the people in his hometown at the same time arouses this meaning. Such interactions expand his perception and modify his pre-knowledge or pre-scribed identity.

Man's progress towards realization is the footprint of his search for identity. Meanwhile, he knows his potentiality. Comparing and contrasting the people and recording their differentiations can help the novelist to reach self-recognition and satisfaction. The national culture is subject to change. Elements which were central may become marginal, and national rituals may change their meaning. The nation also exists in the process by which individuals become aware of themselves as having a national identity. This is an aspect of one's self-formation, and it is in virtue of the success of this process that a person finds himself at home in one social environment rather than another, he comes to feel that his national identity is as natural and inescapable as his gender. Every nation claims its own homeland, one which is described in the national literature, depicted in its art, and celebrated in its music. There is an inevitable elements of myth in the stories which nations tell themselves. Where these two coincide, one's individual identity is confirmed, and reflected in the social life, and as he expresses his identity, he reproduces that form of social life

\section{Real and Fictional Home/Dublin in $A$ Portrait}

Man's life is closely intertwined with his home in all aspects. In the broad sense, the origin of man roots in homeland thus a man can be identified based on his home. According to Baradaran Jamili: 
[h]omeland or Heimat has many significances and infl ences, especially in the life of every human being. Some critics consider home as a synonym for the race (blood) and territory (soil), some others define it as nation, family, homeland and believe in one people, one family, one homeland: belonging together, with common origins. The word Heimat is, rooted in that intolerance of difference, that fear of the 'other,' which is at the heart of racism and xenophobia. (10)

Home, in this sense, can be defined as man's origin. In other words, man is rooted in his homeland or Heimat. At the same time such understanding of home can help man to find his real identity or self-recognition. One's identity, then, is closely related to his home.

Joyce immortalizes the place in order to make it, as Barthes states, in Mythologies (1991), a "[t]ype of speech, a system of communication or a message" (110). By mythologizing his favorite place, he transforms it "from a closed, silent existence to an oral state" which is "open to appropriation" by the literary readers (ibid). Hence, in order to make the place meaningful, an author changes it into a kind of writing and a myth. With an eye to Barthes' definition of myth as "a sum of signs, a global sign," one can see a place as a signifier formed by a sum of signs which is a first semiological system that conveys a meaning (ibid).

According to Baradaran Jamili, these significant places may signify the happy days of childhood, enduring and consoling sense of connection to and unification with the past; they may also tell the story of "the writer's adventures and walking with his mother, father and siblings; they may tell the stories of his school days" (2006:152). The place is a sign, which is a mixture of his past and present experiences. The signifier of myth is as Barthes states, ambiguous as it is simultaneously meaning and form that is "full on one side and empty on the other" (1991: 112). In this way, Clongowes College is considered more than a school for studying, but it is an "imagination space" that anchors the memory of childhood to present (ibid).

In Joycean narrative in A Portrait, as creative writing, the main factor is a sense of place and a sense of the past that changes the mere places and spaces into the mythic forms whose roots are located in the world of reality. Joyce puts Dublin at the very center of the world to make it a myth or "a type of speech chosen by history" (ibid). Joyce mythologizes Heimat in his fictional narratives. For Joyce, Heimat has a unique quality that cannot be found anywhere else, since he depicts Dublin as "the culmination of self-discovery," one that has been fantasized from his early childhood and obviously, his art has the potential of "stabilizing the subjective structure of meaning by miniaturizing the images of the place" (Baradaran Jamili 2013:10).

At the start of the novel, Stephen's engagement with the world is symptomatic of a burgeoning consciousness:

Stephen Dedalus

Class of Elements

Clongowes Wood College

Sallins

\section{County Kildare}

Ireland

Europe

The World

The Universe. (A Portrait 18)

In his geography book at school, he locates himself at the center of a universe radiating out from his own earth-bound existence to infinit . According to Desmond Harding:

[t]his Platonic/Christian conception of the universe, in which the city of Dublin has yet to play a part, finds its correlatives in Stephen's reverence for the simple life and order of the peasants of the village of Clane, whose identity is bound up with a simplistic sense of awe for the mysteriousness of religion, rural life, and the ways of the rural Irish. (15)

The order that Stephen considers for the universe refers to his respect to his name. Stephen Dedalus walks around the city physically and mentally that provides him a real and fictional city or home. Walking around the city can broaden the walker's horizons, make him or her "a citizen of the world" or at least, a better citizen at home (Baradaran Jamili 2006: 20). It is only a power of reasoning because ethos and world view, the approved style of life and the assumed structure of reality, fit together well that they complete one another and lend one another meaning.

As a child Stephen constructs a semantic bridge to the world around him by creating a lexicon based on the memorization of what he perceives to be the denotative and connotative meanings of words: "words which he did not understand he said over and over to himself till he had learned them by heart: and through them he had glimpses of the real world about him" (A Portrait 54). At the same time, the move to Dublin naturally coincides with a psychic shift in the way Stephen becomes inducted into his new environment. The hour to take part in the life of that world seemed drawing close and he secretly began to make ready for the great part. This same natural world beyond the civilizing boundaries of the school engenders in turn sentimental reveries: "[i]t would be lovely to sleep for one night in that cottage before the fire of smoking turf, in the dark lit by the fire, in the warm dark, breathing the smell of the peasant, air and rain and turf and corduroy" (A Portrait 54).

Mediated by Stephen's consciousness, the peasants of Clane lack clear identities; rather, they exist as disembodied figures, or as objects in a receding landscape typically viewed by Stephen and his friends as they pass to and from the railway station. On the whole, while rural Ireland exists beyond the borders of the text, its muted yet enigmatic presence serves to enrich and define Joyce's concept of the culture of metropolitan Dublin in distinct and informing ways. In fact, Joyce portrays the real Dublin in a fictional narrative. Real and fictional home in this way overlap each other.

Davin, the peasant student and ardent nationalist, is taken up by Stephen's imagination as yet another of Joyce's equivocal symbols for Ireland. The suspicion attached to this myth of rural Ireland is again rehearsed toward the end of A Portrait as Stephen prepares to quit Dublin. At this point 
the narrative structure gives way to ports taken directly from Stephen's diary: “14 April: John Alphonsus Mulrennan has just returned from the west of Ireland" (A Portrait 224).

While one is moving by Stephen through $A$ Portrait, all abstract and concrete forms of signs remain central in Stephen's search for his own artistic soul, and are nowhere more apparent than in his relationship to Dublin, the essential ground of Stephen's experience of modernity. However, while Joyce's representation of Dublin lends itself to an examination of the metropolis and mental life, it is actually in the city of Cork that $A$ Portrait provides men with a powerful instance of urban consciousness. Following Stephen's return from Cork, Joyce informs the readers that " $[\mathrm{t}]$ he letters of the name Dublin lay heavily upon his mind, pushing one another surily hither and thither with slow boorish insistence" (A Portrait 98).

But it is in Cork, the scene of his father's final and irrevocable financial dispossession from middle-class Irish life, that Stephen is inexorably pushed beyond the limits of reality. Stephen, who acts as a "moral barometer" for the monstrous images of his own riotous imagination, is further sickened by the trite details of his father's rakish youth, the details of which are paraded before Stephen as they visit "old haunts" and converse with "old cronies" (Harding 93). Stephen is caught between the chaos of his inner life and the weight of external reality, he fumbles awkwardly for a center of meaning while his thought is like fog. But in a cold epiphanic moment, he symbolically breaks with his father, assuming in the process the characteristic feature of "metropolitan consciousness" (ibid).

\section{Desire of Home in $A$ Portrait}

Kath Woodward, in Understanding Identity (2002), states that, "[t]here is often nostalgia attached to home and people away from their first home may experience homesickness and longing" (48). This desire goes further than patriotism and articulates the desire for home as well as giving voice to feelings in order to retain in one's heart, country, people and culture, especially when one is far away. This desire for home can be apprehended according to Roland Barthes' statement, in A Lover's Discourse (1978):

[e]verything follows from this principle: that the lover is not to be reduced to a simple symptomal subject, but rather that we hear in his voice what is "unreal," i.e. intractable. Whence the choice of a "dramatic" method which renounces examples and rests on the single action of a primary language (no metalanguage). The description of the lover's discourse has been replaced by its simulation, and to that discourse has been restored its fundamental person, the I, in order to stage an utterance, not an analysis. What is proposed, then is a portrait- but not a psychological portrait: instead, a structural one which offers the reader a discursive site: the site of someone speaking within himself, amorously, confronting the other (the loved object) who does not speak. (3)

In the case of Joyce, the loved subject is home. Far home is an imaginary construction which tells the readers more about people's hopes and desires than about any actual experience or history. While the longing for home may appear to represent fixing stability and the desire for certainty, it may be more about the desire than the location.

The journeys are the linkage between reality and imaginary. The notion of home in particular crosses the boundaries between the real and the imagined and between the past, the present and the hope for future. It is because of the strength of the desire to have some notion of a home where one belongs that there can be such strong identification with territory and with place, so that identities are more often constructed in relation to the place one has come from than the place one might be going to.

According to Baradaran Jamili (2013), Heimat is about "security and belonging" (9). Origin, belonging, nationality and identity are the first questions in Joyce's mind. He remaps home/Dublin or reconstructs self that fabricates its way all through his life. Through shaping and reshaping his Heimat, he aims at collecting and possessing himself. He needs a new "civilized identity," by which to replace or balance the effect of his incompleteness; hence, he learns to stare at something he is looking for, that is to watch the Dubliners' behavior (ibid). His continuing, almost obsessive use of Irish material is thus merely incidental. Indeed, Dublin which is represented in Joyce's early fiction can be universal. As Ezra Pound in Pound/Joyce (1967), states, "[e]rase the local names and a few specifically local allusions, and a few historic events of the past, and substitute a few different local names, allusions and events, and these stories could be retold of any town" (29).

In this way Pound then, agrees that Joyce's novels exhibit the immense depicting one nation, exemplary in its dishevelment and degradation. He also holds that Joyce's criticism of Ireland depends on the meta-perspective supplied by his participation in a broader European culture, and Pound in particular is concerned to read Irish nationalism in Joyce as a symptom of local idiocy: "[i]f more people had read the The Portrait and certain stories in Mr. Joyce's Dubliners there might have been less recent trouble in Ireland. A clear diagnosis is never without its value" (ibid 90).

One of the ways to search for and understand one's own identity is "home travelling," due to home's role in one's being (Baradaran Jamili 2013: 13). Joyce's home also plays a significant role in all his life from childhood to adulthood. Referring to his three-year-old staying in Clongowes that A Portrait vastly deals with it, Joyce's identity is revealed to the readers that "he was happy there, he was also homesick," thus he "day-dreamed" to go home to postulate about "who he was and what his place was in the universe" (ibid). Being far from home and staying at school, it becomes possible for him to travel between home and school that leads him to ponder on his own identity. Joyce does not hold the same and stable view on his home. In a letter to Nora, Joyce describes his feeling about home:

$[\mathrm{m}] \mathrm{y}$ mind rejects the whole present social order and Christianity-home, the recognized virtues, classes of life, and religious doctrines. How could I like the idea of home? My home was simply a middle-class affair ruined by spendthrift habits which I have inherited. My mother was slowly killed, I think, by my father's ill-treatment, by years of trouble, 
and by my cynical frankness of conduct. When I looked on her face as she lay in her coffin a face grey and wasted with cancer- I understood that I was looking on the face of a victim and I cursed the system which had made her a victim. (L2:48)

On the other hand, in another letter to Stanislaus Joyce, he has a different view about Ireland: "[t]he damned monotonous summer was over and the rain and soft air made me think of the beautiful (I am serious) climate of Ireland" (L2:109). Joyce's "contradictory" views of hometown signify both his "aborted desire" and an "ideal object" in his art that show the reconstruction of his identity based on his home (Baradaran Jamili 2013:12).

By using "Dublin English" in his work, he constructs his hometown to indicate his own "culture", and portrays "a kind of security and belonging" that celebrate the "local Irish" (ibid). As John Nash shows, his "well-known semiautobiographical character, Stephen Dedalus, asserted that Ireland was important insofar as it belonged to him" (108). Thus, it might be considered that from his Irish reception point of view, Joyce was a notable novelist insofar as he belonged to Ireland. He frequently emphasizes this sense of belonging in his works and the way he has been read by his readers.

The land is conceived as a common possession, something that all members of the nation share with each other. The concept of possession is a symbolic one. The homeland is the ground in a near literal sense of national identity. Loss usually carries with it a continuity and deep sense of dislocation and alienation. It is because culture is important to identity, in this sense, that the claim of the individual to his or her own culture has so much force. It is the idea that one comes to understand who he is through the resources provided for him by the forms of social life.

\section{Construction of Identity at Home in $A$ Portrait}

The "writers" hometowns or Heimat" in literary fictions are the subject of interpreting and decoding by the readers in modern novel as in literary works "the cities stand for something other and more than themselves" (Baradaran Jamili 2013: 8). Cities are the representation of kinds of relationships that make it possible for an individual to "construct and reconstruct his/her own identity" (ibid). The individuality of man can be traced to his hometown. The concept of city is under the influence of the concept of home in literary fictions

The act of "remapping the cities" in a novel is the construction of author's "inner" self which shows the connections and relations between the author and his home. Consequently, such remapping paves the way "to construct and reconstruct his/her own national identity" (ibid). Burke and Stets state that, the "self originates in the mind of persons" and an individual becomes conscious of his or her identity through his or her self (9). In other words, the self is one's own being.

The self is an organized set of processes within an individual that accomplishes his outcomes. One's job is to understand that organization, how it occurs and how it both maintains itself and changes over time, grows out of the mind as the interacts with its environment to solve the prob- lem of sustaining the biological organism that holds it. Mind, itself, arises and develops out of social interaction process. Mind is the mechanism that controls the meanings that govern one's responses to the environment. The ability to pick out meanings and to indicate them both to the self and to others gives control to humans. This control is made possible by language, which "encapsulates the meanings in the form of symbols" (ibid 10). It is when one's self is encapsulated as a symbol to which one may respond, as to any other symbol, that self-control becomes possible and the self emerges. The self is individual and social in its character.

Self is to control meaning to support itself, but many of those meanings including the meanings of the self are shared and form the basis of language communication, symbolic interaction and, ultimately, social structure. Because the self becomes visible in social interaction within the context of a complicated differentiated society, because people occupy different positions within society, the self reflects this differentiation into components:

[e]ach of these smaller selves within the overall self is called an identity. Thus, self as father is an identity, as is self as colleague, self as storekeeper, self as student, and self as any of the other myriad of possibilities corresponding to the various roles one may play. Each of these, is a stimulus. Identity, and each may act as an agent instigating behavior within the different roles. Identities are also important because they provide as with ties to others and to what is social in a situation. Part of their content consists of symbols and meanings pertaining to the self. In order to discuss these symbols and meanings, we need to turn to the second of the three central concepts: language. (Burke 10)

The social network is made up of someone's daily route and locale. It involves a person's interactions with a fixed group of people, such as friends, family, neighbors, and coworkers, who can offer material, emotional, or logistical support. Baradaran Jamili argues that, taking a walk in the streets of hometown paves the way for every novelist to meet "diverse aspects of life," and observe different places which provide enough motifs to "formulate and reshape one's own identity" (2013:8). Joyce is in the search of his identity at home by revealing and dealing with it in his works. He imagines his Heimat, Dublin, and shows how it can be treated as a "metaphorical map" (ibid). He, indeed, provides a condition of self-knowledge at home.

Joyce not only does make his home permanent object by mapping it in his works, but also he constructs or reconstructs his own Irish identity. He uses the real names of actual pubs, restaurants, railway companies. He has written to Frank Budgen in Letters of James Joyce (1957): "I want to give a picture of Dublin so complete that if the city one day suddenly disappeared from the earth it could be reconstructed out of my book" (L1:199).

\section{CONCLUSION}

The fate of individual identity is revealed in city life that is the combination of multiple factors such as social forces, historical background, culture and technique of life. Joyce portrays an image of Dublin and Ireland that is the conglom- 
eration of his different visions. He views his home from in and out, thus he has a universal viewpoint upon it. Culture can be considered as a context. If one needs to know himself, he should find a way to the cultural context that he has been brought up in it.

If a Dubliner walks with Stephen in A Portrait, he becomes conscious of himself. His identity has been shaped under the influence of real people and places that he names frequently in this story. A Portrait, according to Joyce, is the picture of his spiritual life that makes it possible for him to know his being in this universe. He wants to know the order of his place as a Dubliner among all the elements of this world. Joyce portrays his home from his childhood when he is at home with his family as the first matter that influences his identity. He leaves his home for the first time at seven for school. He gets the concept of homesickness at school. He longs for home where he seeks peace and security in it. In A Portrait, Joyce shows how a person constructs his identity at home. In other words, he becomes to know who he is through his home.

In this work, Joyce is revealed as an Irish and Dubliner that is his real identity. In his debates with his friends, he emphasizes the place of nation. It is premier to anything for him even family and religion. Even though the most important thing for him is his home/Dublin, he is not a nationalist. His home is his identity. He defines himself as an Irish even after departing and living in other countries and cities.

\section{REFERENCES}

Arnold, Kathleen R. Homelessness- citizenship and identity. New York: State U, 2004.
Baradaran Jamili, Leila. "Reconstructing identity through remapping Dublin: James Joyce's Heimat." International Journal of Language and Literature 1:2 (2013) 8-17. .Virginia Woolf: Traveling, Travel Writing and Travel Fictions. Berlin U, 2006.

Barthes, Roland. A Lover's Discourse. Trans. Richard Howard. New Zealand: Penguin Books, 1978.

Elements of Semiology. Trans. Annette Lavers and Colin Smith. New York: Hill and Wang, 1986.

---------------. Mythologies. Trans. Annette Lavers. New York: The Nooday Press, 1991.

Burke, Peter J., and Ja. E Stets. Identity Theory. Oxford: Oxford UP, 2004.

Harding, Desmond. Writing the City: Urban Visions \& Literary Modernism. London:

Routledge, 2003.

Joyce, James. A Portrait of the Artist as a Young Man. 2016. Ed. Jeri Johnson. New York: Oxford UP, 2000.

Letters of James Joyce. Vol. 1: 1904-1940. Ed. Stuart Gilbert. New York: Viking P.1957.

Nash, John. "In the Heart of the Hibernian Metropolis? Joyce's Reception in Ireland, 1900-1940.” A Companion to James Joyce, ed. Richards Brown. New York: Wiley-Blackwell, 2011. 108-122.

Poole, Ross. Nation and Identity. London: Routledge, 1999.

Prevos, Peter. "Cultural Identity." Foundations of Social Science (2004) 1-5.

Ryan, Michael. Cultural Studies: A Practical Introduction. West Sussex: Willey-Blackwell, 2010.

Woodward, Kath. Understanding Identity. London: Arnold, 2002 . 